Original Research Paper

\title{
Physic-Geographic Factors of Oil Development in the Chechen Republic
}

\author{
Umar Tashadievich Gayrabekov, Alexey Nikolaevich Gunja and Tumisha Khamidovna Bachaeva
}

FSBEE HPE the Chechen State University, Sheripova Str., 32, Grozny, Russia, 366907, Russia

\author{
Article history \\ Received: 06-07-2014 \\ Revised: 03-12-2014 \\ Accepted: 15-12-2014 \\ Corresponding Author: \\ Umar Tashadievich \\ Gayrabekov, \\ FSBEE HPE the Chechen \\ State University, Sheripova \\ Str., 32, Grozny, Russia, \\ 366907, Russia \\ E-mail: mtrushin@mail.ru
}

\begin{abstract}
Oil development in the Chechen Republic for a long time has led to formation of widespread and inwardly heterogeneous area of oil development business impact on the natural complexes in the neighborhood. Therefore, authors have set the goal of detecting physic-geographical factors of the area where oil has been intensively developed for almost two centuries. The research made by the authors showed that the most widespread technogenic loads are related to many technical objects-wells, intra-and inter-oilfield oil ducts, pits, sediment basins, etc. These technical facilities that are served by Oil and Gas Production Units (OGPU) are the most powerful sources of impact on the landscape structure. Basing on analysis of materials of the field study, map-making, statistical and find materials, the authors managed to identify physic-geographical factors of oil production in the Chechen Republic that are manifested in concentration in certain narrow landscape units of certain oil production facilities. Technogenic loads on the landscape are related to it. Detailed study of worked-out pits made at the territory of the republic showed that accumulated drilling waste in its composition and physic-chemical properties are sources of environment pollution. Sludge storage pits made with violation of ecological requirements may filter and allow liquid fractions of drilling waste through walls and bottom of pits. Confinedness of oil deposits to submontane and montane zone of the republic, according to authors' opinion, defines the necessity of developing special methodological approaches to the analysis and assessment of the impact of oil production facilities in the fragile and dynamic mountain landscapes.
\end{abstract}

Keywords: Oil Production, Environment, Environment Pollution, Sludge Storage Pits

\section{Introduction}

As a rule, oil production is accompanied by emergency and technogenic leakages, oil spills on the surface of the earth. Pollution of the soil with oil causes deviations in dynamic equilibrium in the ecosystem due to changes in soil cover structure, geochemical properties of the soils and toxic effect on living organisms (Pikovskiy et al., 2003).

Empirically and experimentally unequal rate was detected for separate oil products migration in soils: the less the viscosity is, the lower the rate is. In unsaturated areas of soil, oil migrates slower than water (Kessler, 1985 ; 1987). Under otherwise equal conditions oil and oil products migrate to the greatest depth in the substrates with light mechanical composition (Eizenhut, 1969; Bartz, 1969; Lippok, 1966; NMIMT, 1989). As observed by Eizenhut (1969), oil products (naphta) 2 years after the pollution were found at the depth of 8.65 m (loamy loesses); after two days-at the depth of $2.25 \mathrm{~m}$ (clay-loam with boulder); steadily set at the depth of 8.5 $\mathrm{m}$ after 7 years (sandy clay-loam).

There are a few published materials about experimental research of migration-oil and oil products fixation in natural conditions (Glazovskaya and Pirovsky, 1985; Solntseva et al., 1996; Eizenhut, 1969; Bartz, 1969), on samples of earth with undisturbed structure (Guseva and Solntseva, 1996) and on sandy models (Lippok, 1966).

Experimental confirmation of secondary agility of oil in soils of various areas in Russia and neighboring and other states has been obtained by (Bartz, 1969; Faingold, 1971; Glazovskaya and Pikovsky, 1985; Akhmedov et al., 1982).

Territorial ratios of indications of primary and secondary landscape violations depend on their resistance: The more resistant natural systems are, the less there are secondary changes, which fact is confirmed by actual data (Walker et al., 1987). 
The processes of soil, fresh water and landscape pollution and their distant consequences have been poorly described in the literature. One of the reasons for this state is the fact that most of scientific research of the impact of oil and gas production complex on the environment in a number of countries remains closed and research materials are not published (Pimlott, 1977). In spite of that, many works of both domestic and foreign researchers devoted to certain aspects of oil production influence on the environment have recently appeared.

As shown by these studies, in oil production, organic and mineral substances of both natural and anthropogenic origin have penetrated landscapes for years. Factors of pollutants impacts on the ecology that is typical for oil production, on the one hand, depend on quantity and composition of pollutants, i.e., their geochemical activity and on the other hand, on properties of natural systems penetrated by these substances. Same substances in different landscapegeochemical conditions behave differently: In some cases, they are stable and even inert, while in other cases they are not only subjected to rapid transformations, but also actively interact with the soilground mass (Solntseva, 1988; 1998a; 1998b). In this case there is no developed system of methods of gentle nature management and recovery of environmental disturbances, although there are many experimental and methodical studies of the prevention and stabilization of some unwanted processes and rehabilitation of such lands (Mc Gill, 1977; De Jong, 1980).

The Chechen Republic is one of the oldest areas of oil production and refining in the country and in the world, where technological transformation of the natural environment occurred as a result of long-term functioning of oil production complex. The reason for pollution of natural and anthropogenic environment of the republic was low level of ecological friendliness of processes used for oil production, as well as emergency situations that lead to release of various pollutants into the environment (Kerimov and Uzdieva, 2008; Gayrabekov et al., 2012; Gayrabekov, 2012a). Since major oil deposits of the republic are confined to the active orogenic region, morphostructural conditions play a very important role in stability of oil occurrence and development conditions. This, in turn, affects technogenic transformation of natural-anthropogenic environment of the region (Gayrabekov, 2012b). Therefore, issues related to the physical and geographical features of oil production in the Chechen Republic as a mountainous region where many oil fields have been developed for a long time using low-tech drill waste management schemes are still relevant.

\section{Materials and Methods}

The work is based on the results of the research made by the authors in order to assess the impact of oil facilities on the environment of the Chechen Republic.
We used map-making, statistical materials and literature sources on this topic. Landscape-geochemical and mapmaking research methods were used.

\section{Results}

Physiographic features of oil production in the Chechen Republic are manifested in certain concentrations in landscape units of various oil production, transportation, storage and processing facilities. At the regional level, oil and gas deposits are confined to the so called "nodes", i.e., locations of physiographic boundaries of high rank (Fig. 1).

The problem of recognizing large accumulations of hydrocarbons was solved by various authors (Guberman and Pikovsky, 2004) in the framework of various concepts, among which the concept of morphostructural units should be emphasized. According to this concept, activity of natural processes increases at border crossings of crustal blocks-areas of active interruption. It was found that large accumulations of oil and gas occur in the territory of morphostructural units. I.e., locations of block border crossings (Guberman and Pikovskiy, 2004; Guberman et al., 1997).

To understand the nature of the impact of oil production facilities, a detailed analysis of local objects and elements of the entire oil production system is required.

Elementary level of local objects and elements of the entire oil production system are drilling sites interconnected into shops. Today in the Chechen Republic 221 oil wells are being operated, each with two pits. 4,701 wells have been drilled throughout the history of oil production. Currently, there are four цеха добычи нефти и газа in the area that deliver oil via pipelines to refineries and an oil-loading station. In fact they are the most important centers of impact on the landscape structure. Saturation with "point" (drill sites, pits, storage facilities) and linear (girths) objects allows speaking of natural landscapes transformation to naturalanthropogenic and anthropogenic (Fig. 2).

Dimensional level of the shop in submontane and montane zones corresponds to the natural complexes of countryside and landscape rank. However, in lowland conditions, this dimensional level may greatly increase, up to several landscapes. Drill sites are confined to the natural territorial complexes of stow rank.

Four shops and the refinery occupy a vast area (Fig. $3)$. The level of impact captures natural territorial complexes of several landscapes. As already was mentioned, ecotones are affected, i.e., natural systems at the border of major physiographic boundaries.

Greatest danger to natural-anthropogenic environment in course of oil wells construction are production and technological drill wastes, i.e., Drilling Wastewater (DWW), the Waste Drilling Mud (WDM), 
Cutting Slurry (CS) and products of well development and testing. All these wastes are accumulated and stored directly on the drill site, usually in earth storage pits for drill waste made in mineral or made soil.

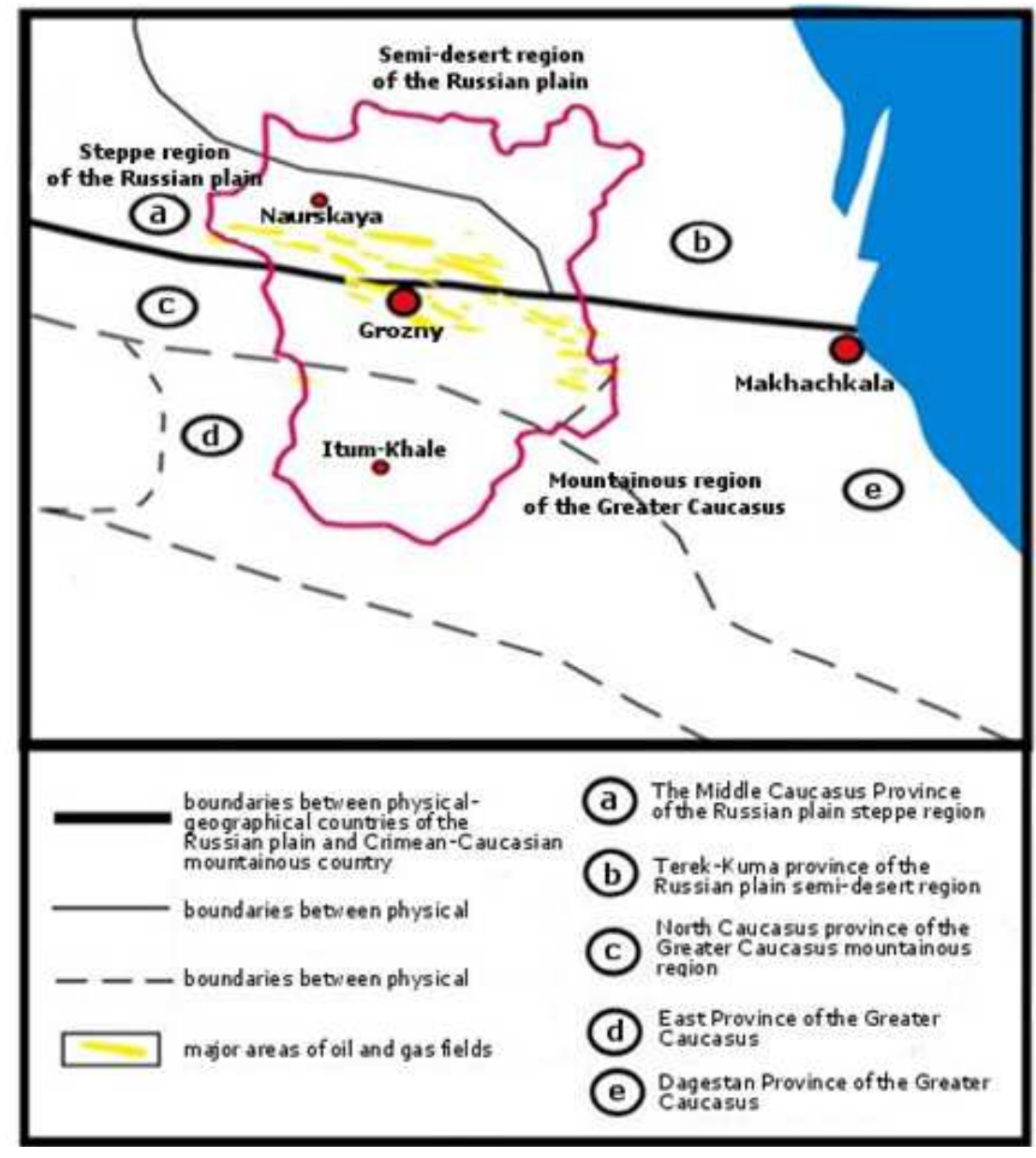

Fig. 1. Major areas of oil and gas fields in the Chechen Republic, superimposed on a map of physical and geographical regionalization (physical and geographical regionalization of the USSR, 1986)

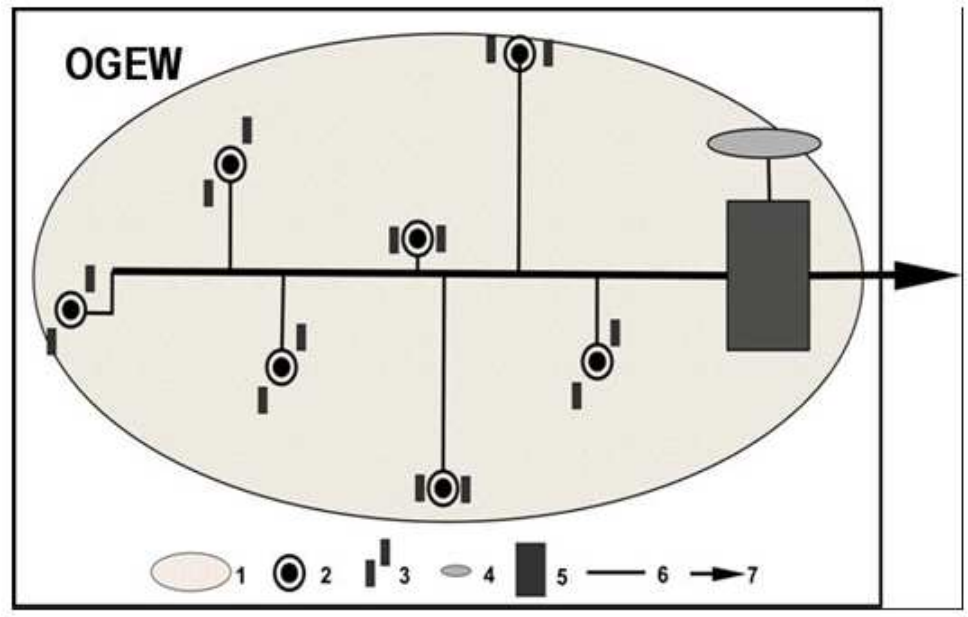

Fig. 2. Schematic diagram of Oil and Gas Extraction Workshop (OGEW)-Range profound impact on the landscape structure. Numbers: 1-field (localized area of oil and gas-bearing rocks), 2-drilling, 3-barns, 4-oil traps, 5-intermediate storage unit, 6inter-field pipelines (harness), 7-oil pipeline leading to a refinery 


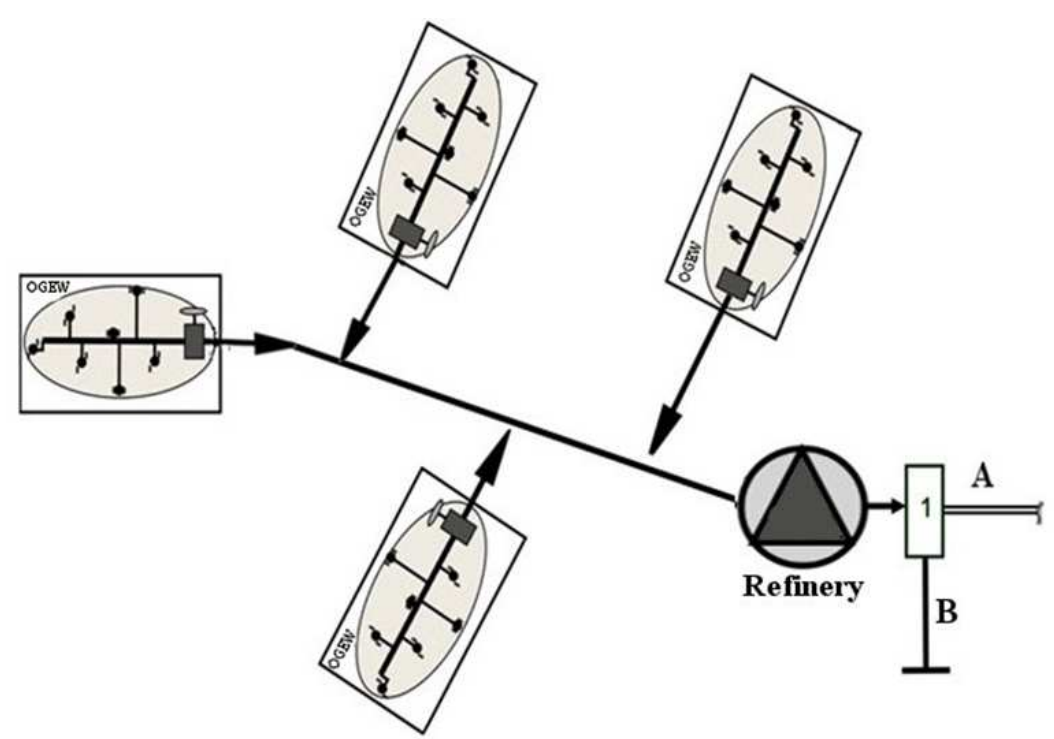

Fig. 3. Schematic diagram of workshops and refineries connection and further transportation of petroleum products. Numerals indicate the transportation options from storage tanks (1): A-through the main pipeline B-through the flyover (for pumping in the tank)

Drilling wastes contain a wide range of pollutants of mineral and organic nature represented by minerals and chemicals used for preparation and treatment of drilling fluids (Milutin et al., 2013).

Within the territory of the Chechen Republic (Mollaev and Saitov, 1991) studies have been made in order to determine composition and properties of drilling wastes that have been accumulated in the waste pits and evaluation of their impact on the environment. The studies made it possible to classify pits as long-term sources of chemical contamination of the environment, where macrocomponent (salt), microcomponent (heavy metals) and hydrocarbon (oil) pollutants have been identified. Negative impact of pits on natural and anthropogenic environment is assessed by the hazard of chemicals and materials they contain.

\section{Discussion}

It is known that oil production is among leaders in relation to the impact on the environment. Large scale oil production is usually accompanied by mechanical disturbances in landscapes and chemical contamination of the environment.

The uniqueness of environmental problems in oil production is due to three factors: Specifics of composition and properties of produced formation fluid, technology of its extraction and features of geographical conditions in production areas (Solntseva, 1988).

Study of anthropogenic impact of sludge pits on the environment showed that they either have no waterproofing at all, or it is damaged and their contents penetrates the soil to the depth of $80 \mathrm{~m}$. When waste drilling mud gets into soil, soil enzymes are destroyed, thereby reducing productivity of soil cover (Tetelmin and Yazev, 2009). Besides, long-term sludge storage in pits promotes hydrocarbons binding with soil particles, which over the years leads to concentration of compounds with high molecular weight, which is a constant source of toxic, mutagenic and carcinogenic hydrocarbons (Popova, 2012).

By the impact of oil production on surface water and ground water, results of studies performed on the territory of the Chechen Republic using indicator methods (Mollaev and Saitov, 1991) showed the presence of the connectivity between pits and groundwater.

Assessment of the impact of drilling waste on the soils and vegetation showed that vegetation is almost universally absent at the reclaimed sites.

Thus, studies made by a number of authors in various environmental conditions showed that oil production sites are the most important sources of environment pollution. Therefore, the problem of environmentally safe arrangement and operation of oil complex facilities in montane and premontane areas with complex geological and geographical conditions is an urgent problem not only at the regional but at the national scale as well.

\section{Conclusion}

Intensive development of the oil industry in the premontane and montane areas, building and operation of numerous oil facilities have led to massive impact on the environment of the Chechen Republic, to natural 
landscape complexes transformation to naturalanthropogenic and anthropogenic ones. The process of oil and gas development on the territory of the Chechen Republic that has lasted for two centuries has led to formation of extensive and internally heterogeneous area of oil industry impact on the surrounding natural systems. One of the reasons of this situation is the low level of ecological friendliness of the processes used for oil production, as well as emergency situations that lead to escape of various pollutants into the environment. Another reason is lack of theoretical basis for protection of the environment in premontane and montane areas where the Chechen Republic belongs. Therefore, in order to ensure environmental safety a program for fastest Republic's environment rehabilitation, arising from oil complex long-term operation in its territory.

Physiographic features of oil production in the Chechen Republic are manifested in certain concentrations in landscape units of various oil production facilities that are associated with the most important sources of technogenic loads on the landscape environment.

Detailed study of worked-out pits showed that accumulated drilling waste in its composition and physic-chemical properties are sources of environment pollution.

Confinedness of oil deposits to submontane and montane zone of the republic defines the necessity of developing special methodological approaches to the analysis and assessment of the impact of oil production facilities in the fragile and dynamic mountain landscapes.

\section{Author's Contributions}

All authors equally contributed in this work.

\section{Ethics}

This article is original and contains unpublished material. The corresponding author confirms that all of the other authors have read and approved the manuscript and no ethical issues involved.

\section{References}

Pikovskiy, Y.I., A.N. Gennadiev and S.S. Chernyansky, 2003. Problems of diagnosis and rationing of soil contamination with oil and oil products. Soil Sci., 9: 1132-1140.

Kessler, A. and H. Rubin, 1985. On the simulation of unsaturated oil flow in soil. 153: 195-205.

Kessler, A. and H. Rubin, 1987. Relationships between water infiltration and oil spill migration in sandy soils. J. Hydrol., 91: 187-204. DOI: $10.1016 / 0022-1694(87) 90204-6$
Eizenhut, E., 1969. Gesteinsabhangigkeit bei auswirkung von olunfalen. Gesungheits-Ingenier, 90: 49-51.

Bartz, J., 1969. Ol und Bensinversickerungsvarsuche in der Oberrheinebene. Gas Und Wasserfach, 110: 592-595.

Lippok, W., 1966. Model versuche uber das verhalten von heizol EI im porosen medium. Koblenz, Deutsche Dewasserkundliche Mitteilungen, 10: 145-157.

NMIMT, 1989. Laboratory Investigation of Residual Liquid Organics from Spills, Leaks and the Disposal of Hazardous Wastes in Groundwater, 1989. New Mexico Institute of Mining and Technology, Socorro. pp: 285.

Glazovskaya, M.A. and Y.I. Pikovskiy, 1985. Complex experiment for studying factors of self-purification and remediation of oil-contaminated soils in various natural zones. Migration of contaminants in soils and neighboring environments. Proceeding of the Annals of 3rd All-Soviet Meeting, (ASM' 85), Obninsk, Leningrad, pp: 185-191.

Solntseva, N.P., O.A. Gusev and S.V. Goriachkin, 1996. Modeling oil and oil products migration processes in the tundra soils of the European part of Russia. Series Soil Sci., 2: 10-17.

Akhmedov, A.G., N.P. Ilyin, N.M. Ismailov and Y.I. Pikovskiy, 1982. Factors of Heavy Oil Degradation in Light Gray-Brown Soils of Dry Azerbaijan Subtropics. Mining and Geochemistry of Natural Ecosystems. Moscow.

Guseva, O.A. and N.P. Solntseva, 1996. Modelling of oil bearing and oil yielding capacities tundra landscape soils at the European part of Russia (EPR). Proceedings of the 4th International Symposium on the Geochemistry of the Earth Surface, (GES' 96), GetInfo, pp: 4I7-420.

Faingold, A., 1971. Oil spills in the Arctic. Proceedings, 2: 131-140.

Walker, D.A., P.J. Webber, E.F. Binnian, K.R. Everett and N.D. Ledere et al., 1987. Cumulative impacts of oil fields on Northern Alaskan landscapes. Science, 238: 757-761. PMID: 17814703

Pimlott, D.H., 1977. The development of petroleum Resources in the Canadian Arctic: Perspective on the evolution of environmental and social policies. J. Arctic Syst., 2: 353-371. DOI: 10.1007/978-1-4684-0799-0 19

Solntseva, N.P., 1988. General ways of soils transformation in areas of oil production (manifestations, key processes, models). Nauka, Moscow.

Solntseva, N.P., 1998. Oil Production and Geochemistry of Natural Landscapes. 1st Edn., Moscow State University Editing House, Moscow, pp: 376.

Solntseva, N.P., 1998. Oil Mining and Geochemical Transformation of Landscapes. 1st Edn., Moscow University Press, Moscow, pp: 376. 
Mc Gill, W.B., 1977. Soil restoration following oill spills-a review. 16: 60-67. DOI: 10.2118/77-02-07

De Jong, E., 1980. Reclamation problems and procedures for the oil industry on the Canadian prairies. Reclamat. Revi., 3: 75-85.

Kerimov, I.A. and N.S. Uzdieva, 2008. Geoecology of Chechen Republic Oil Production Complex. 1st Edn., Pilgrim, Nazran, pp: 252.

Gayrabekov, U.T., R.H. Dadashev, I.A. Karimov, A.A. Daukaev and A.H. Usmanov, 2012. Development of the Chechen Republic oil production complex and problems of geological environment pollution. History Sci. Technol., 7: 40-44.

Gayrabekov, U.T., 2012. Spatial and temporal effects of a montane region natural-anthropogenic environment transformation in the area of an oil complex influence. Prospects Sci., 6: 196-198.

Gayrabekov, U.T., 2012. Factors of oil fields distribution in premontane and montane areas of the world. Bulletin Acad. Sci. Chechen Republic, 17: 114-121.

Guberman, S.A. and Y.I. Pikovsky, 2004. Predicting Major Oil and Gas Fields in Modern Block Structure of Earth's Crust (Morphostructural Units and Oiland-Gas Content). In: Morphostructural UnitsLocations of Extreme Natural Phenomena, Ramtsan, E.Y. and M.P. Glasko (Eds.), Media-Press, Moscow, pp: 224-224.
Guberman, S., Y. Pikovski and E. Rantsman, 1997. Methodology for prediction of the locations of giant oil and gas reservoirs: Field results. Proceedings of the SPE, Western Regional Meeting Held in Long Beach, Jun. 25-27, California, pp: 321-330.

Milutin, A.G., N.K. Androsova, I.S. Kalinin and A.K. Portsevsky, 2013. Ecology. Fundamentals of Environmental Geoscience. In: Textbook for Bachelors. Milutin, A.G. Ed, Uright Publishing House, Moscow, pp: 542.

Mollaev, R.H. and H.D. Saitov, 1991. Influence of drilling waste accumulated in earth slime on the environment. Ecological problems of ChechenoIngushetia and neighboring regions. Proceedings of the North Caucasus Regional Scientific-Practical Conference, (SPR' 91), Grozny, pp: 22.

Tetelmin, V.V. and V.A. Yazev, 2009. Hydrocarbons Geoecology. 1st Edn., House"Intelligence", pp: 304.

Popova, G.G., 2012. To develop a method of ecological rehabilitation of oily waste sludge tanks. Mining Information-Analytical Bulletin, Moscow. 